Article

\title{
Facile Synthesis of Flower-Like Copper-Cobalt Sulfide as Binder-Free Faradaic Electrodes for Supercapacitors with Improved Electrochemical Properties
}

\author{
Tianlei Wang, Meitang Liu * and Hongwen Ma* \\ Beijing Key Laboratory of Materials Utilization of Nonmetallic Minerals and Solid Wastes, \\ National Laboratory of Mineral Materials, School of Materials Science and Technology, \\ China University of Geosciences, Beijing 100083, China; wangtl@cugb.edu.cn \\ * Correspondence: mtliu@cugb.edu.cn (M.L.); mahw@cugb.edu.cn (H.M.) \\ Academic Editor: Shirley Chiang \\ Received: 8 May 2017; Accepted: 1 June 2017; Published: 7 June 2017
}

\begin{abstract}
Supercapacitors have been one of the highest potential candidates for energy storage because of their significant advantages beyond rechargeable batteries in terms of large power density, short recharging time, and long cycle lifespan. In this work, $\mathrm{Cu}-\mathrm{Co}$ sulfides with uniform flower-like structure have been successfully obtained via a traditional two-step hydrothermal method. The as-fabricated $\mathrm{Cu}-\mathrm{Co}$ sulfide vulcanized from precursor ( $\mathrm{P}-\mathrm{Cu}-\mathrm{Co}$ sulfide) is able to deliver superior specific capacitance of $592 \mathrm{~F} \mathrm{~g}^{-1}$ at $1 \mathrm{~A} \mathrm{~g}^{-1}$ and $518 \mathrm{~F} \mathrm{~g}^{-1}$ at $10 \mathrm{~A} \mathrm{~g}^{-1}$ which are surprisingly about 1.44 times and 2.39 times higher than those of $\mathrm{Cu}-\mathrm{Co}$ oxide electrode, respectively. At the same time, excellent cycling stability of $\mathrm{P}-\mathrm{Cu}-\mathrm{Co}$ sulfide is indicated by $90.4 \%$ capacitance retention at high current density of $10 \mathrm{~A} \mathrm{~g}^{-1}$ after 3000 cycles. Because of the introduction of sulfur during the vulcanization process, these new developed sulfides can get more flexible structure and larger reaction surface area, and will own richer redox reaction sites between the interfaces of active material/electrolyte. The uniform flower-like $\mathrm{P}-\mathrm{Cu}-\mathrm{Co}$ sulfide electrode materials will have more potential alternatives for oxides electrode materials in the future.
\end{abstract}

Keywords: copper-cobalt sulfide; electrode material; hydrothermal method; binder-free

\section{Introduction}

With the urgent targets to deal with the crisis of energy depletion, enthusiastic exploration of the environmental and efficient energy materials are engaged [1-3]. Supercapacitors, as a type of newly-emerging energy storage devices, have attracted tremendous attention for their ultrahigh power density and excellent electrochemical stability [4-9]. Therefore, lots of research has been conducted to improve the energy density under the precondition of maintaining their power density and long lifespan [10-15].

It is well-known that cobalt oxides are putative promising materials as electrodes with outstanding electrochemical property [16-19]. However, the single-metal oxides are sometimes limited to their broad application which are suffering from poor rate capability, poor charge-discharge reversibility, high cost for their raw materials, and high toxicity [20,21]. Sorts of attempts have been implemented to seek eco-friendly and less expensive metal element (such as $\mathrm{Cu}, \mathrm{Zn}, \mathrm{Ni}, \mathrm{Mg}$, and $\mathrm{Fe}$ ) to replace the toxic and expensive Co aiming at the development of low cost and sustainable electrodes [21-27]. $\mathrm{MnCo}_{2} \mathrm{O}_{4}$, synthesized via facile hydrothermal method, has been designed as an energy storage device which displays excellent electrochemical properties [28]. As well, ternary metal oxides with 
nanowires [29], nanosheets [30,31], hollow spheres [32], core/shell [25,32-35], and flower-like [36,37] structures directly arraying on $\mathrm{Ni}$ foam exhibit significantly enhanced electrochemical performance.

Copper has been considered as a fascinating candidate instead of cobalt, due to its abundant natural resources, low cost, excellent chemical stability, and environmentally friendly capability. Due to its lots of advantages for electrochemical sensing, a sequence-specific DNA electrochemical biosensor was designed successfully based on CuS nanosheets [38]. Wang et al. reported core@shell $\mathrm{CuCo}_{2} \mathrm{O}_{4} @ \mathrm{MnO}_{2}$ nanoarchitectures with a heightening specific capacitance, outstanding rate capability, and long-term lifespan in different bent states [25]. At the same time, novel and efficient flexible electrodes based on $\mathrm{CuCo}_{2} \mathrm{O}_{4}$ nanowires grown on $\mathrm{Ni}$ wire exhibit outstanding cycling stability and excellent flexible feature, which will make it possible to design wearable electronic devices [39].

In particular, notable transition metal sulfide electrode materials with high electrochemical activity have attracted amount of attention. Generally, due to the lower band gap, transition metal sulfides may exhibit much higher conductivity and lower electronegativity than corresponding transition metal oxides [40-42]. $\mathrm{Ni@rGO}-\mathrm{Co}_{3} \mathrm{~S}_{4}$ and $\mathrm{Ni@rGO}-\mathrm{Ni}_{3} \mathrm{~S}_{2}$ were synthesized as electrodes of advanced aqueous asymmetric supercapacitors, which are beneficial for improving the energy density accompanied by high cycle stability [43]. Yu et al. fabricated $\mathrm{Ni}_{x} \mathrm{Co}_{3-x} \mathrm{~S}_{4}$ electrodes with hollow prisms microstructure via self-templating method, which exhibit high specific capacitance, desirable rate capability and good capacitance retention [26]. In our previous work, we successfully synthesized flower-like Mn-Co oxysulfide in which oxygen element in Mn-Co oxide is partially substituted by sulphur [37]. Recently, hierarchical $\mathrm{CuCo}_{2} \mathrm{~S}_{4}$ hollow nanoneedles are synthesized via template-free hydrothermal method and designed as notable high-performance electrodes with superior electrochemical performances [44].

Based on the above considerations, we prepared the uniform flower-like $\mathrm{Cu}-\mathrm{Co}$ sulfides arraying on $\mathrm{Ni}$ foam by traditional hydrothermal method for the first time. In particular, after making a comparison between $\mathrm{Cu}-\mathrm{Co}$ oxides and $\mathrm{Cu}-\mathrm{Co}$ sulfides which are respectively treated from $\mathrm{Cu}-\mathrm{Co}$ precursor or $\mathrm{Cu}-\mathrm{Co}$ oxide, we conclude the specific capacitance and rate capability of $\mathrm{Cu}$-Co sulfides are superior to those of $\mathrm{Cu}-\mathrm{Co}$ oxides. Besides, $\mathrm{Cu}-\mathrm{Co}$ sulfide by vulcanizing from precursor has advantages over $\mathrm{Cu}-\mathrm{Co}$ sulfide from oxide in those aspects. As a result, hopeful electrodes with fancy specific capacitance, wonderful rate capability, and interesting long-term cycling stability were synthesized, which is expected to be potential candidates for designing, constructing, and developing novel energy storage devices.

\section{Results}

Regardless of the two highest peaks indicating Ni foam, all the diffraction peaks in Figure 1a can be well indexed as CoO (JCPDS 48-1719) and CuO (JCPDS 01-1117), which indicate that the $\mathrm{Cu}-\mathrm{Co}$ oxides is polycrystalline. After $\mathrm{Cu}-\mathrm{Co}$ precursor being vulcanized by $\mathrm{Na}_{2} \mathrm{~S} \cdot 9 \mathrm{H}_{2} \mathrm{O}$, four peaks corresponding to the (113), (004), (115), and (044) diffraction planes are in accordance with the cubic phase of $\mathrm{CuCo}_{2} \mathrm{~S}_{4}$ (JCPDS 42-1450). The other diffraction peaks about (102), (110), and (103) can be well indexed to the standard X-Ray Diffraction (XRD) patterns of $\mathrm{Cu}_{2} \mathrm{~S}$ (JCPDS 26-1116). It is manifested that the $\mathrm{Cu}-\mathrm{Co}$ precursor is completely vulcanized and transformed into the polycrystalline $\mathrm{CuCo}_{2} \mathrm{~S}_{4}$ and $\mathrm{Cu}_{2} \mathrm{~S}$ (Figure $1 \mathrm{~b}$ ). As for O-Cu-Co sulfide, $\mathrm{Cu}_{1.96} \mathrm{~S}$ (JCPDS 29-0578) whose diffraction peaks correspond to the (103), (104), and (202) diffraction planes are accompanied with the phase of $\mathrm{CuCo}_{2} \mathrm{~S}_{4}$, indicating sulphur can entirely take the place of oxygen in the $\mathrm{Cu}-\mathrm{Co}$ oxides during the vulcanizing process, and finally polycrystalline $\mathrm{CuCo}_{2} \mathrm{~S}_{4}$ and $\mathrm{Cu}_{1.96} \mathrm{~S}$ sulfides can be obtained (Figure 1c).

In Figures 2a and 3a, the presence of $\mathrm{Cu}, \mathrm{Co}$, and $\mathrm{S}$ elements in the $\mathrm{Cu}-\mathrm{Co}$ sulfides are indicated in the full-survey scan spectrum. Meanwhile, $\mathrm{O} 1 \mathrm{~s}$ peaks can also be found because the surface of samples were oxidized in the air [45]. According to XPS spectrum for Co $2 p$ in Figures $2 b$ and $3 b$, the binding energies at 781.0 and $797.2 \mathrm{eV}$ of $\mathrm{Co} 2 \mathrm{p}_{3 / 2}$ and $2 \mathrm{p}_{1 / 2}$ peaks accompanied with two satellite peaks at around 786.4 and $802.9 \mathrm{eV}$ are found, which demonstrate the existence of $\mathrm{Co}^{2+}$. Two peaks at binding energies of 932.5 and $952.4 \mathrm{eV}(\Delta \mathrm{E}=19.9 \mathrm{eV})$ are shown in Figures $2 \mathrm{c}$ and $3 \mathrm{c}$ which corresponds to 
the $\mathrm{Cu} 2 \mathrm{p}_{3 / 2}$ and $2 \mathrm{p}_{1 / 2}$ matched with $\mathrm{Cu}^{0}$ or $\mathrm{Cu}^{1+}$. According to XRD analysis, the pure copper does not appear in $\mathrm{P}-\mathrm{Cu}-\mathrm{Co}$ sulfide and $\mathrm{O}-\mathrm{Cu}-\mathrm{Co}$ sulfide, so the copper element exists as $\mathrm{Cu}^{1+}$. At the same time, there is a weak peak at binding energies of $934.8 \mathrm{eV}$ with a satellite peak at $943.3 \mathrm{eV}$, which indicate the $\mathrm{Cu}^{2+}[46,47]$. As for the S 2p XPS spectrum (in Figures $2 \mathrm{~d}$ and $3 \mathrm{~d}$ ), the major peak at the binding energy of $162.5 \mathrm{eV}$ coupled with satellite peak attribute to metal-sulfur bonding ( $\mathrm{Cu}-\mathrm{S}$ and Co-S bonding) [40]. Meanwhile, the binding energy centered at $168.0 \mathrm{eV}$ matches with S-O bonding due to the oxidation effect on the samples in air. The XPS results, being consistent with the XRD results, indicate that the vulcanizing process is effective for $\mathrm{Cu}-\mathrm{Co}$ compounds.
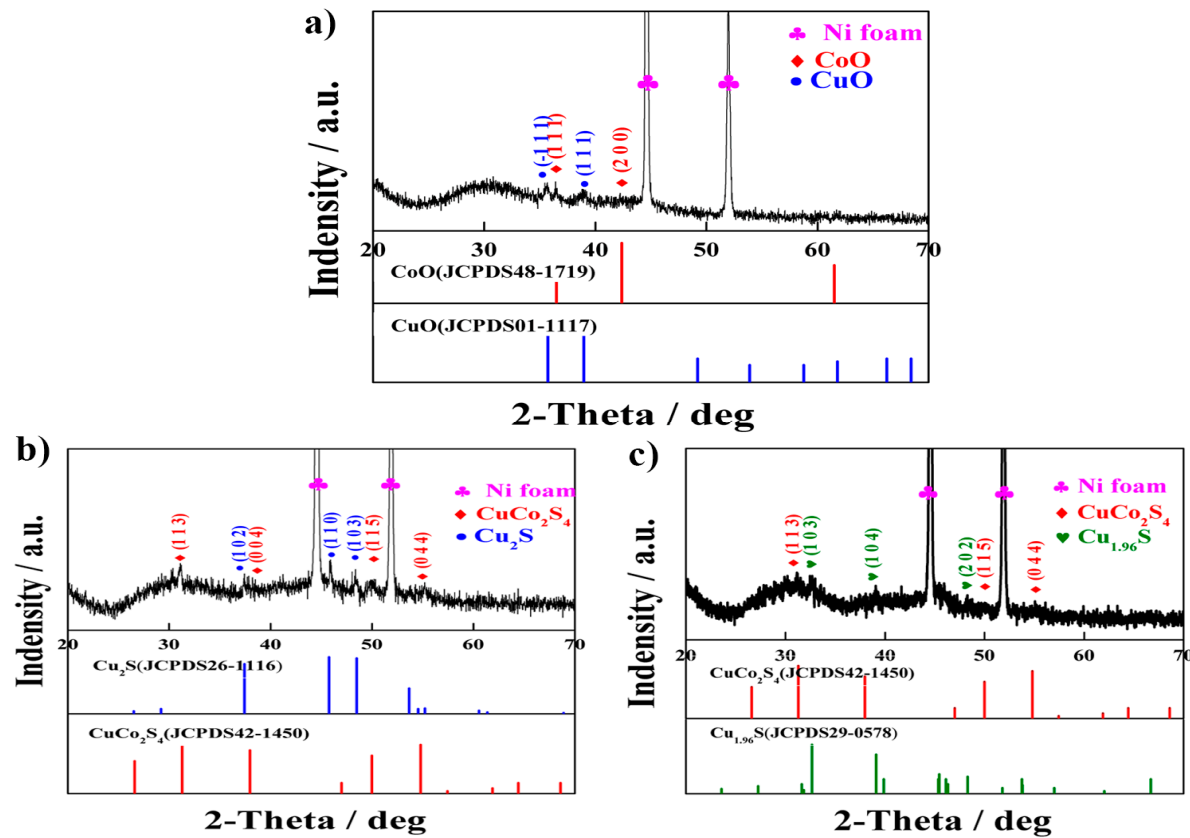

Figure 1. XRD patterns of sample on nickel foam, (a) $\mathrm{Cu}-\mathrm{Co}$ oxide; (b) $\mathrm{P}-\mathrm{Cu}-\mathrm{Co}$ sulfide; (c) $\mathrm{O}-\mathrm{Cu}-\mathrm{Co}$ sulfide.
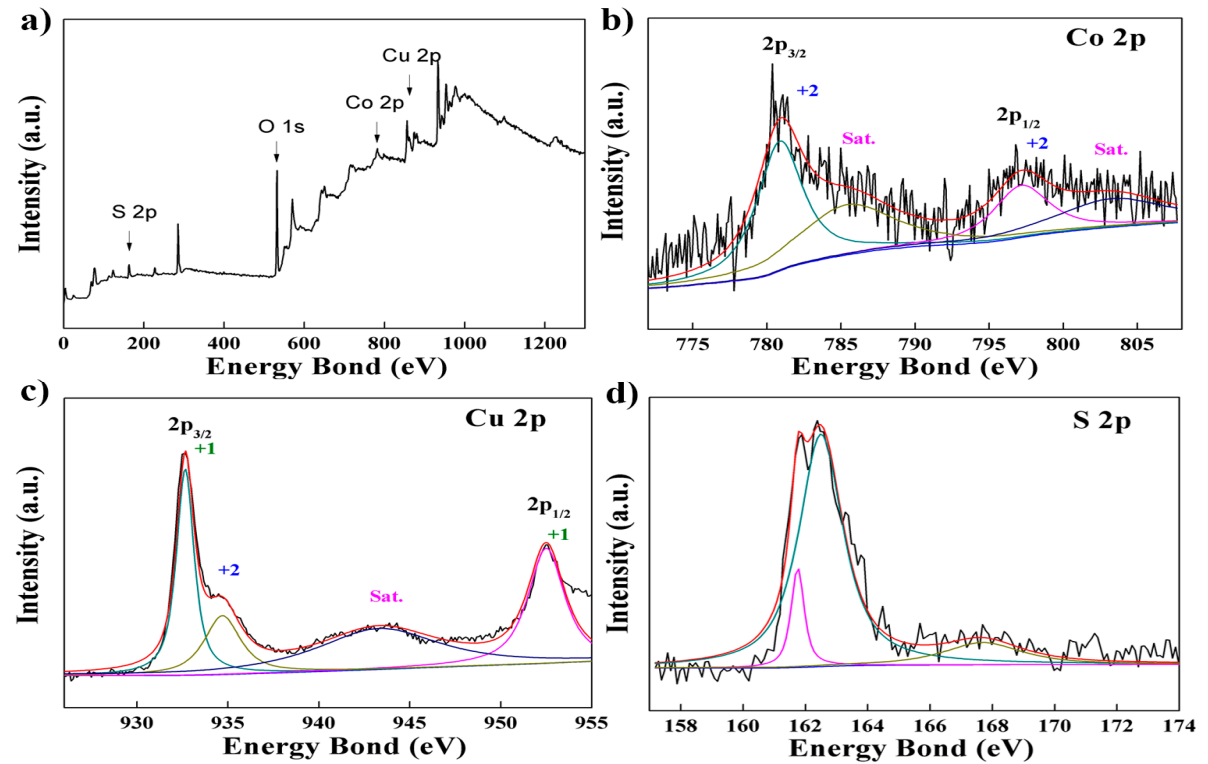

Figure 2. (a) The full-survey scan spectrum of $\mathrm{P}-\mathrm{Cu}-\mathrm{Co}$ sulfide; (b) high resolution spectra of Co 2p; (c) high resolution spectra of $\mathrm{Cu} 2 \mathrm{p}$; (d) high resolution spectra of $\mathrm{S} 2 \mathrm{p}$. 

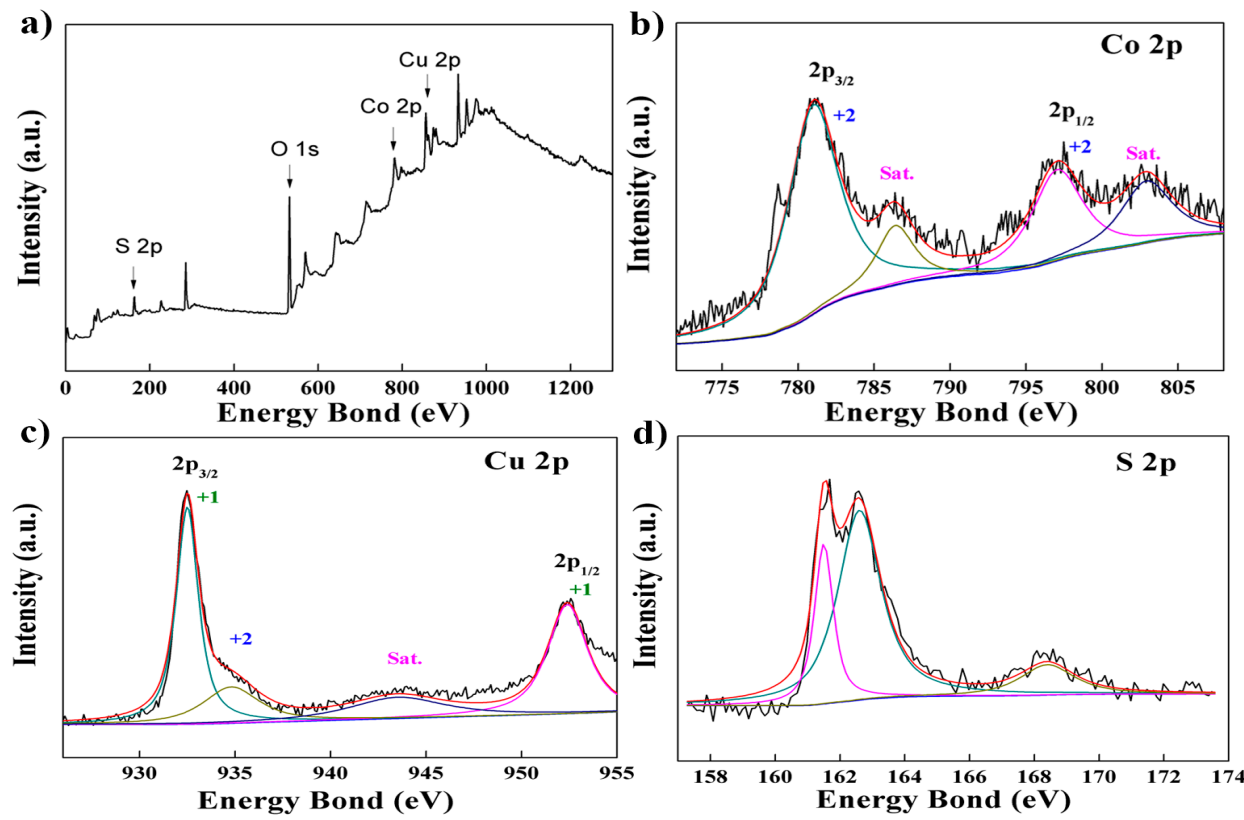

Figure 3. (a) The full-survey scan spectrum of $\mathrm{O}-\mathrm{Cu}-\mathrm{Co}$ sulfide; (b) high resolution spectra of $\mathrm{Co} 2 \mathrm{p}$; (c) high resolution spectra of $\mathrm{Cu} 2 \mathrm{p}$; (d) high resolution spectra of $\mathrm{S} 2 \mathrm{p}$.

Figure 4 exhibits the Scanning Electron Microscope (SEM) images of $\mathrm{Cu}-\mathrm{Co}$ oxide (Figure $4 \mathrm{a}, \mathrm{b}$ ), $\mathrm{P}-\mathrm{Cu}-\mathrm{Co}$ sulfide (Figure 4c,d) and O-Cu-Co sulfide (Figure 4e,f) supported on nickel foam. Cu-Co oxides and sulfides nanoparticles evenly array on the $\mathrm{Ni}$ foam with flower-like structures. As seen from Figure $4 \mathrm{~b}$, the uniform flower-like structure of $\mathrm{Cu}$-Co oxide is stacked by interconnecting nanosheets in different orientations, and the surfaces of nanosheets are regular and smooth. The average diameter of flower structure is about $6.5 \mu \mathrm{m}$ and the nanosheets' thickness is about $160 \mathrm{~nm}$. Normally, the contact area with the perfect flower-like structure between active material and the electrolyte must be much larger than that of other structures. As a result, the uniform flower-like structure must be more suitable for Faradaic reaction. For P-Cu-Co sulfide, the edges of nanosheets are dimmed, and every nanosheet seems to be crosslinked to make the petal grown after sulfuration. The average diameter of flowers grow up to $10.5 \mu \mathrm{m}$. On the contrary, $\mathrm{O}-\mathrm{Cu}-\mathrm{Co}$ sulfide also displays the flower-like structure, but plenty of circular particles appear on the regular and smooth nanosheets. During the vulcanization of $\mathrm{Cu}-\mathrm{Co}$ precursor without any calcining whose nanosheets have not yet fully formed, $\mathrm{OH}^{-}$in precursor are substituted by $\mathrm{S}^{2-}$ leading to the flower growing larger and the nanosheets dimming. In contrast, $\mathrm{Cu}-\mathrm{Co}$ oxide has stable structure after calcination, and the nanosheets do not change when $\mathrm{S}^{2-}$ replaces $\mathrm{O}^{2-}$ during the vulcanization process, only some spherical particles appear on it. Therefore, the flower-like morphology of $\mathrm{Cu}-\mathrm{Co}$ sulfides provides vast channels and large surface areas for electrolyte ions which can make more efficient use of the electrode active materials.

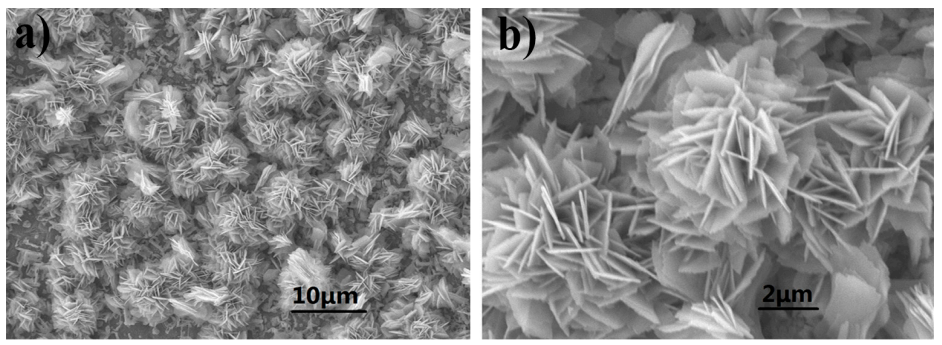

Figure 4. Cont. 


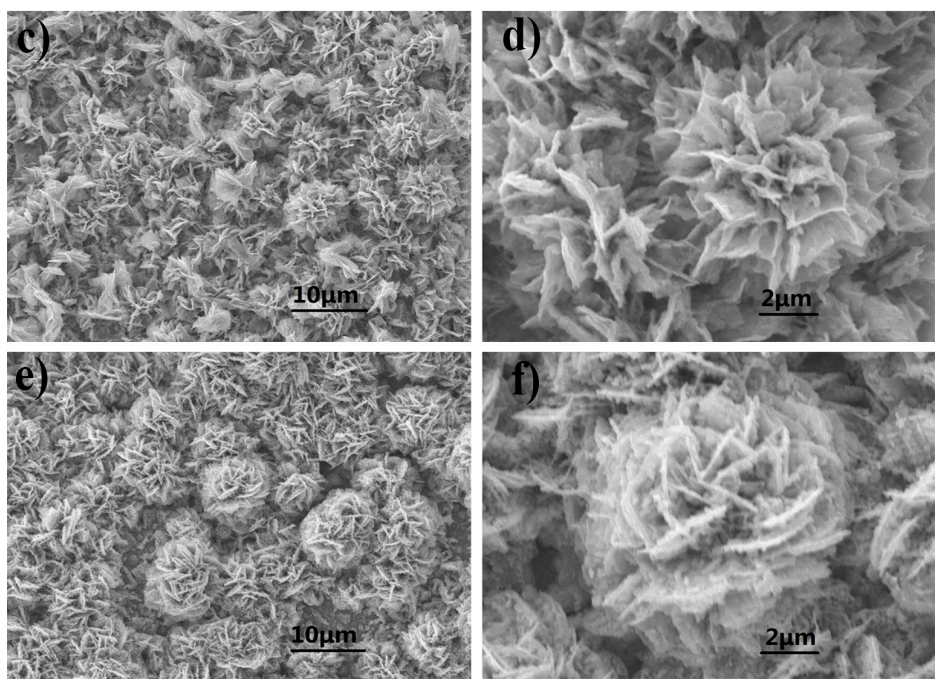

Figure 4. (a,b) SEM images of Cu-Co oxide; (c,d) SEM images of P-Cu-Co sulfide; (e,f) SEM images of $\mathrm{O}-\mathrm{Cu}-\mathrm{Co}$ sulfide.

In the cyclic voltammetry $(\mathrm{CV})$ curves of $\mathrm{Cu}-\mathrm{Co}$ oxide (Figure 5a), it is clear that two pairs of redox peaks can be observed which indicates the typical Faradaic redox reactions occurring in the electrochemical process. At a scan rate of $100 \mathrm{mV} \mathrm{s}^{-1}$, peaks of redox pairs are respectively located at $0.30 \mathrm{~V}, 0.41 \mathrm{~V}$ and $0.42 \mathrm{~V}, 0.49 \mathrm{~V}$ which represent the conversion of $\mathrm{Cu}(\mathrm{I}) / \mathrm{Cu}(\mathrm{II})$ and $\mathrm{Co}-\mathrm{O} / \mathrm{Co}-\mathrm{O}-\mathrm{OH}$ respectively. The redox reactions of $\mathrm{Cu}-\mathrm{Co}$ oxide are described by the Equations (1)-(6) [46-48]. The pair of redox peaks for two kinds of $\mathrm{Cu}-\mathrm{Co}$ sulfides are also testified that they belong to typical electrode material for Faradaic pseudo capacitor, respectively (Figure 5b,c). Meanwhile, the oxidation peaks move to high voltage accompanied with sweep rates growing, and the reduction peaks shift into low voltage synchronously, which is conformed to quasi-reversible characteristic of redox reaction [45]. In term of the shape of $\mathrm{CV}$ curves, it is relatively stable when the sweep rates increase, indicating the electrode material have excellent rate capability.

$$
\begin{gathered}
\mathrm{Cu}_{2} \mathrm{O}+2 \mathrm{OH}^{-} \leftrightarrow 2 \mathrm{CuO}+\mathrm{H}_{2} \mathrm{O}+2 \mathrm{e}^{-} \\
\mathrm{Cu}_{2} \mathrm{O}+\mathrm{H}_{2} \mathrm{O}+2 \mathrm{OH}^{-} \leftrightarrow 2 \mathrm{Cu}(\mathrm{OH})_{2}+2 \mathrm{e}^{-} \\
\mathrm{CuOH}+\mathrm{OH}^{-} \leftrightarrow \mathrm{CuO}+\mathrm{H}_{2} \mathrm{O}+\mathrm{e}^{-} \\
\mathrm{CuOH}+\mathrm{OH}^{-} \leftrightarrow \mathrm{Cu}(\mathrm{OH})_{2}+\mathrm{e}^{-} \\
\mathrm{CoO}+\mathrm{OH}^{-} \leftrightarrow \mathrm{CoOOH}+\mathrm{e}^{-} \\
\mathrm{CoOOH}+\mathrm{OH}^{-} \leftrightarrow \mathrm{CoO}_{2}+\mathrm{H}_{2} \mathrm{O}+\mathrm{e}^{-}
\end{gathered}
$$

In Figure 5d, the plateau regions in galvanostatical charged and discharged (GCD) curves of $\mathrm{Cu}-\mathrm{Co}$ oxide are not distinct because their two couples of redox peaks display slightly difference in potential. As a result, more various redox reactions for $\mathrm{Cu}-\mathrm{Co}$ oxide will occur. While the GCD curves of $\mathrm{Cu}-\mathrm{Co}$ sulfides exhibit distinct plateau regions which correspond to the redox peaks in the $\mathrm{CV}$ curves, giving the evidence of the faradaic behaviors during redox reaction process between electrode/electrolyte interfaces. Meanwhile, for comparison, the discharged times of $\mathrm{Cu}-\mathrm{Co}$ sulfides are almost 2-2.5 fold to those of $\mathrm{Cu}-\mathrm{Co}$ oxides at a current density of $1 \mathrm{~A} \mathrm{~g}^{-1}$. The specific capacitance $\left(\mathrm{F}^{-1}\right)$ of $\mathrm{Cu}-\mathrm{Co}$ oxide and sulfides are counted using different discharge current densities as shown in Figure 5g. At current densities of $1 \mathrm{~A} \mathrm{~g}^{-1}$, the specific capacitance of $\mathrm{Cu}-\mathrm{Co}$ oxide, $\mathrm{P}-\mathrm{Cu}-\mathrm{Co}$ sulfide and $\mathrm{O}-\mathrm{Cu}-\mathrm{Co}$ sulfide is 243,592 , and $482 \mathrm{~F} \mathrm{~g}^{-1}$, respectively. Surprisingly, specific capacitance of $\mathrm{P}-\mathrm{Cu}-\mathrm{Co}$ sulfide is 1.44 times higher than that of $\mathrm{Cu}-\mathrm{Co}$ oxide. To increase current densities to $10 \mathrm{~A} \mathrm{~g}^{-1}$, 
specific capacitance of $\mathrm{Cu}$-Co oxide, $\mathrm{P}-\mathrm{Cu}-\mathrm{Co}$ sulfide, and $\mathrm{O}-\mathrm{Cu}-\mathrm{Co}$ sulfide can maintain 153, 518, and $341 \mathrm{~F} \mathrm{~g}^{-1}$, separately. Fascinatedly, specific capacitance of $\mathrm{P}-\mathrm{Cu}-\mathrm{Co}$ sulfide is 2.39 times higher than that of $\mathrm{Cu}-\mathrm{Co}$ oxide. In addition, when the discharge current densities increase, $\mathrm{Cu}-\mathrm{Co}$ oxide only keep $63.0 \%$ retention of the capacitance, but $\mathrm{P}-\mathrm{Cu}-\mathrm{Co}$ sulfide unexpectedly hold $87.5 \%$ retention which implies good rate capability. By comparison, the specific capacitance and rate capability of $\mathrm{Cu}-\mathrm{Co}$ sulfides can be superior to those of $\mathrm{Cu}-\mathrm{Co}$ oxide, and $\mathrm{P}-\mathrm{Cu}-\mathrm{Co}$ sulfide have advantages over $\mathrm{O}-\mathrm{Cu}-\mathrm{Co}$ sulfide in those aspects. When the discharge current density increases, the migration and diffusion of electrolyte ions does not catch up with the reaction rate, as a result the specific values decrease gradually. This phenomenon gives the indirect evidence to the existence of the faradaic behaviors in the redox reaction [49].
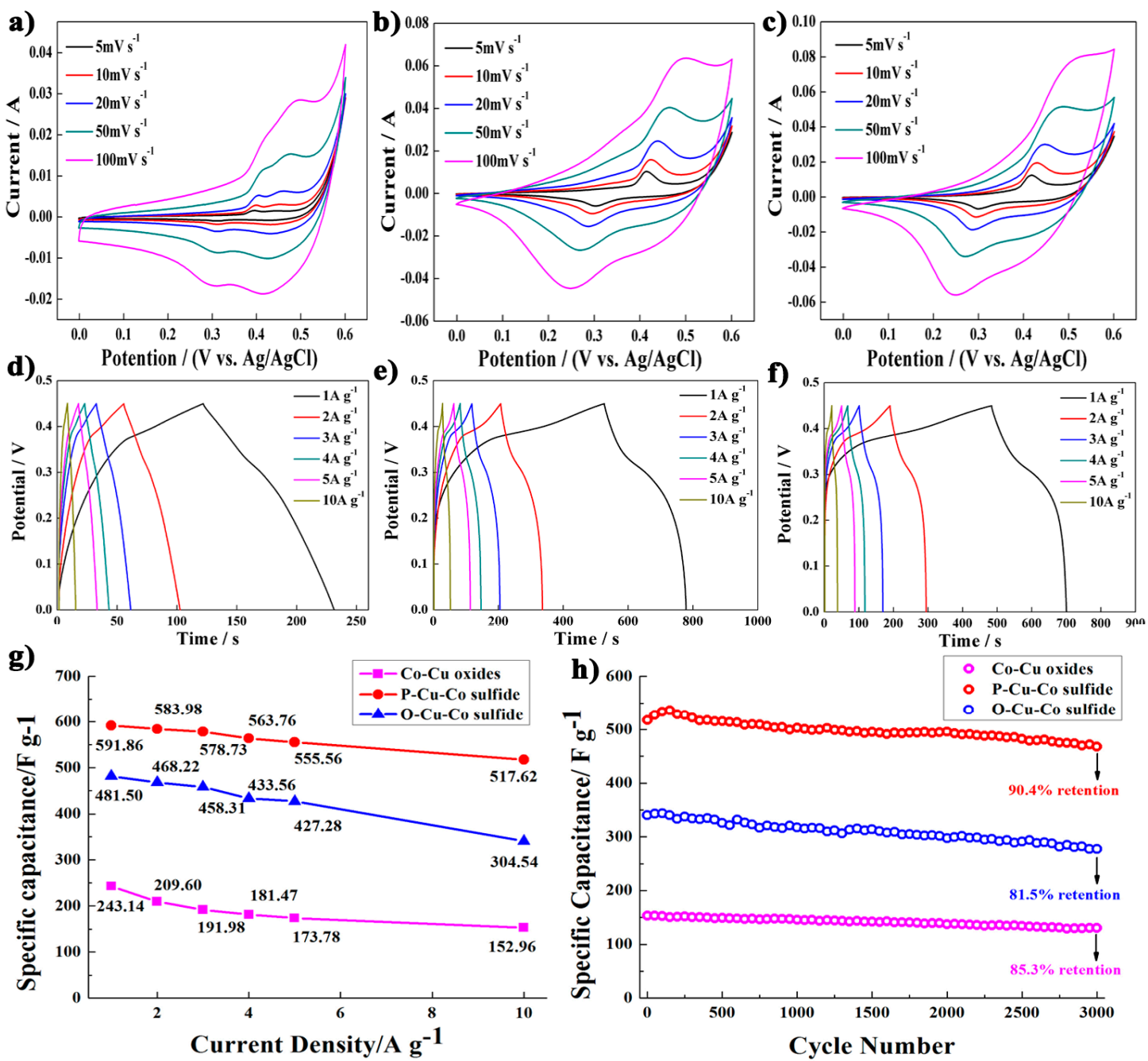

Figure 5. (a) CV curves of $\mathrm{Cu}-\mathrm{Co}$ oxide; (b) CV curves of $\mathrm{P}-\mathrm{Cu}-\mathrm{Co}$ sulfide; (c) $\mathrm{CV}$ curves of $\mathrm{O}-\mathrm{Cu}-\mathrm{Co}$ sulfide; (d) GCD plots of Cu-Co oxide; (e) GCD plots of P-Cu-Co sulfide; (f) GCD plots of O-Cu-Co sulfide; (g) Specific capacity of $\mathrm{Cu}-\mathrm{Co}$ oxide, $\mathrm{P}-\mathrm{Cu}-\mathrm{Co}$ sulfide, and $\mathrm{O}-\mathrm{Cu}-\mathrm{Co}$ sulfide; (h) Cycling performance of $\mathrm{Cu}-\mathrm{Co}$ oxide, $\mathrm{P}-\mathrm{Cu}-\mathrm{Co}$ sulfide, and $\mathrm{O}-\mathrm{Cu}-\mathrm{Co}$ sulfide at a current density of $10 \mathrm{~A} \mathrm{~g}^{-1}$.

Moreover, repeating GCD measurements for 3000 cycles were investigated in order to test the cycle stabilities of $\mathrm{Cu}-\mathrm{Co}$ oxides or sulfides at a current density of $10 \mathrm{~A} \mathrm{~g}^{-1}$, as shown in Figure $5 \mathrm{~h}$. Due to the deformation of the nanosheets structure during the repetitive charge/discharge process, the specific capacities have a gradual decline along with the cycle number increasing. After 3000 cycles, $\mathrm{P}-\mathrm{Cu}-\mathrm{Co}$ sulfide still keeps a high specific capacitance of $468 \mathrm{~F} \mathrm{~g}^{-1}$ with $9.6 \%$ degradation $(90.4 \%$ retention) but the degradation of $\mathrm{Cu}-\mathrm{Co}$ oxide is $14.7 \%$ and that of $\mathrm{O}-\mathrm{Cu}-\mathrm{Co}$ sulfide is $18.5 \%$, which 
indicates that P-Cu-Co sulfide has excellent cycle stability. Figure 6 shows the morphology of electrode materials after 3000 cycles at a current density of $10 \mathrm{~A} \mathrm{~g}^{-1}$, the frameworks of $\mathrm{Cu}-\mathrm{Co}$ oxide and sulfides still remain well after cycling, which indicate that they have good stiffness and structural stability.
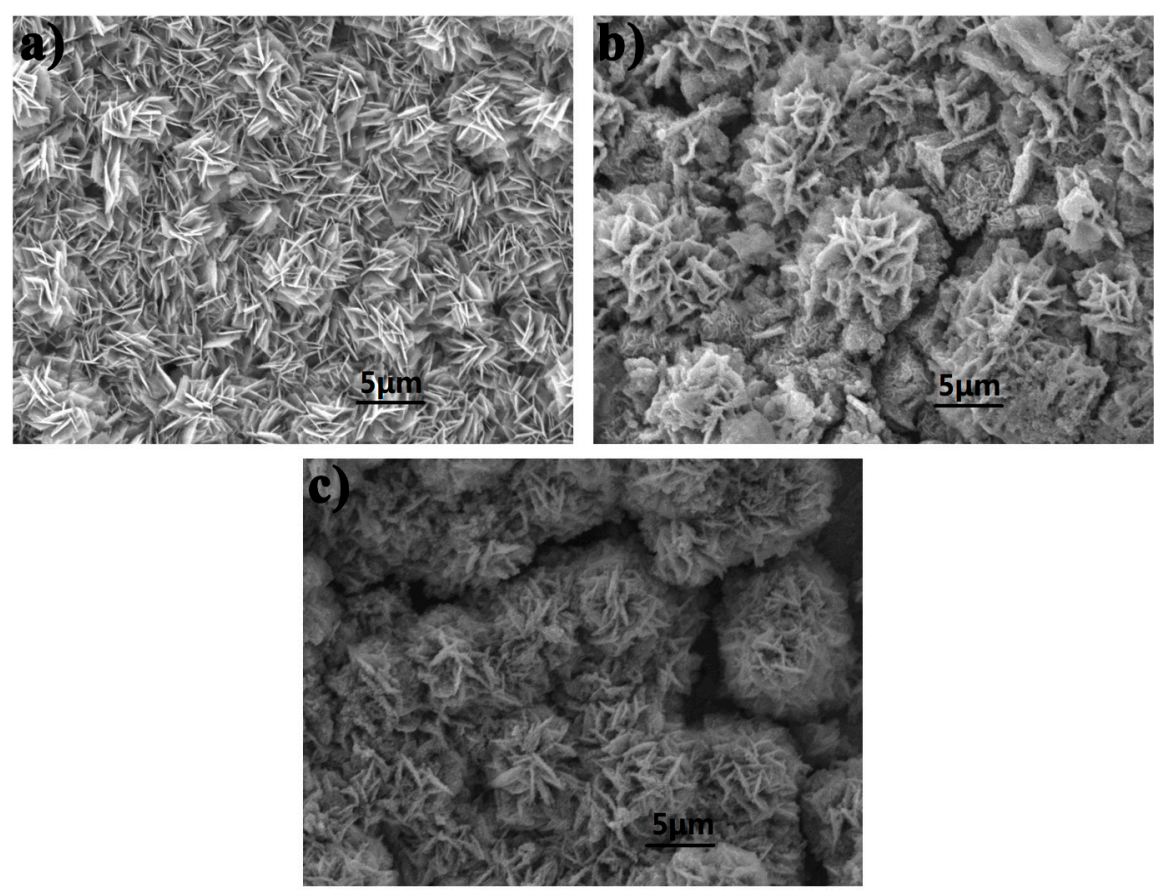

Figure 6. SEM images of samples after 3000 cycles at a current density of $10 \mathrm{~A} \mathrm{~g}^{-1}$, (a) Cu-Co oxide; (b) P-Cu-Co sulfide; (c) O-Cu-Co sulfide.

\section{Discussion}

The electrochemical property of $\mathrm{Cu}-\mathrm{Co}$ sulfides are meaningfully superior to that of $\mathrm{Cu}-\mathrm{Co}$ oxides. However, more importantly, $\mathrm{P}-\mathrm{Cu}-\mathrm{Co}$ sulfide is surprisingly superior to $\mathrm{O}-\mathrm{Cu}-\mathrm{Co}$ sulfide in terms of electronic properties. The first factor of excellent performances of $\mathrm{Cu}-\mathrm{Co}$ sulfides is that the flower-like nanosheet structure effectively provide the numerous electroactive sites bring the wide electrode-electrolyte surface/interface and facilitate the charge-transfer reactions [31,32,34]. Secondly, it is helpful to promote the conductivity property because the electroactive material connects directly to Ni foam substrate without binders [25,43]. Thirdly, $\mathrm{Cu}-\mathrm{Co}$ sulfides have richer redox reaction due to the lower electronegativity of sulfur and more flexible structure owing to the substitution of oxygen to sulfur [42-44]. Finally, without calcination process, P-Cu-Co sulfide with low crystallinity is beneficial for faradaic reaction $[26,33,36]$.

\section{Materials and Methods}

\subsection{Reagents and Method}

All the reagents are of analytical grade. $\mathrm{Co}\left(\mathrm{NO}_{3}\right)_{2} \cdot 6 \mathrm{H}_{2} \mathrm{O}, \mathrm{Cu}\left(\mathrm{NO}_{3}\right)_{2} \cdot 3 \mathrm{H}_{2} \mathrm{O}, \mathrm{Na}_{2} \mathrm{~S}$ and urea were supplied by Sinopharm Chemical Reagent Co. Ltd (Beijing, China).

The as-pressed nickel foam substrates with $2 \times 2 \mathrm{~cm}^{2}$ in size were cleaned in $\mathrm{HCl}$ solution and deionized water for each $15 \mathrm{~min}$ under ultrasonication. Typically, $1 \mathrm{mmol}$ of $\mathrm{Cu}\left(\mathrm{NO}_{3}\right)_{2} \cdot 3 \mathrm{H}_{2} \mathrm{O}$, $2 \mathrm{mmol}$ of $\mathrm{Co}\left(\mathrm{NO}_{3}\right)_{2} \cdot 6 \mathrm{H}_{2} \mathrm{O}$ and $9 \mathrm{mmol}$ of urea were dissolved in $35 \mathrm{~mL}$ of deionized water under magnetic stirring for $30 \mathrm{~min}$. The solution was poured in $50 \mathrm{~mL}$ Teflon-lined stainless steel autoclave with a pretreated and weighted $\mathrm{Ni}$ foam, and then maintained at $120{ }^{\circ} \mathrm{C}$ for $4 \mathrm{~h}$. Subsequently, the as-synthesized $\mathrm{Cu}-\mathrm{Co}$ precursor loaded on $\mathrm{Ni}$ foams were ultrasonically cleaned with water for $1 \mathrm{~min}$. The $\mathrm{Cu}-\mathrm{Co}$ precursor was annealed at $350{ }^{\circ} \mathrm{C}$ in air for $2 \mathrm{~h}$ in order to fabricate $\mathrm{Cu}-\mathrm{Co}$ oxide. 
The $\mathrm{Cu}-\mathrm{Co}$ sulfides were prepared by the sulfuration of $\mathrm{Cu}-\mathrm{Co}$ precursor or $\mathrm{Cu}-\mathrm{Co}$ oxide with $10 \mathrm{~mL}$ $0.1 \mathrm{M}$ sodium sulfide at $120^{\circ} \mathrm{C}$ for $6 \mathrm{~h}$. The $\mathrm{Cu}-\mathrm{Co}$ sulfide obtained from precursor was recorded as $\mathrm{P}-\mathrm{Cu}-\mathrm{Co}$ sulfide, while the sulfide from $\mathrm{Cu}-\mathrm{Co}$ oxide was marked as $\mathrm{O}-\mathrm{Cu}-\mathrm{Co}$ sulfide.

\subsection{Electrochemical Measurements}

In traditional three-electrode cell configuration, electrolyte is $1 \mathrm{M} \mathrm{KOH}$ aqueous solution, and the as-synthesized $\mathrm{Cu}$-Co oxides or sulfides electrodes were used as the working electrodes, while Pt wire and $\mathrm{Ag} / \mathrm{AgCl}$ electrodes were used as reference and counter electrodes, respectively. CV measurements were performed in the voltage range of 0 to $0.6 \mathrm{~V}$ (vs. $\mathrm{Ag} / \mathrm{AgCl}$ ). The as-synthesized $\mathrm{Cu}-\mathrm{Co}$ oxides or sulfides electrodes were galvanostatically charged and discharged at different current densities between 1 and $10 \mathrm{~A} \mathrm{~g}^{-1}$.

\section{Conclusions}

To sum up, this work successfully synthesized uniform flower-like $\mathrm{Cu}$-Co sulfide supported on nickel foam by facile two-step hydrothermal method. The differences of $\mathrm{Cu}-\mathrm{Co}$ oxide, $\mathrm{P}-\mathrm{Cu}-\mathrm{Co}$ sulfide, and $\mathrm{O}-\mathrm{Cu}-\mathrm{Co}$ sulfide in morphology and electrochemical properties are systematically discussed. According to the results, $\mathrm{P}-\mathrm{Cu}-\mathrm{Co}$ sulfide electrode displays dramatically excellent electrochemical properties which performs superior specific capacity of $592 \mathrm{~F} \mathrm{~g}^{-1}$ at $1 \mathrm{~A} \mathrm{~g}^{-1}$ and $518 \mathrm{~F} \mathrm{~g}^{-1}$ at $10 \mathrm{~A} \mathrm{~g}^{-1}$, about 1.44 times and 2.39 times higher than those of $\mathrm{Cu}-\mathrm{Co}$ oxide electrode, respectively. Therefore, the $\mathrm{P}-\mathrm{Cu}-\mathrm{Co}$ sulfide is expected to be a potential candidate for manipulating, controlling, and investigating novel rechargeable charge storage devices. Further works are ongoing with the research on electrochemical performance of shape-controlled hierarchical multi-metal sulfides.

Acknowledgments: This work was supported partially by the National Natural Science Foundation of China (Grant No. 40802013), the Fundamental Research Funds for the Central Universities (Grant No. 2652016057, 2652015007).

Author Contributions: Tianlei Wang, Meitang Liu, and Hongwen Ma conceived and designed the experiments; Tianlei Wang performed the experiments; Tianlei Wang, Meitang Liu, and Hongwen Ma analyzed the data; Tianlei Wang wrote the paper.

Conflicts of Interest: The authors declare no conflict of interest. The founding sponsors had no role in the design of the study; in the collection, analyses, or interpretation of data; in the writing of the manuscript, and in the decision to publish the results.

\section{References}

1. Poizot, P.; Laruelle, S.; Grugeon, S.; Dupont, L.; Tarascon, J.M. Nano-sized Transition-metal Oxides as Negative-electrode Materials for Lithium-ion Batteries. Nature 2000, 407, 496-499. [CrossRef] [PubMed]

2. Tollefson, J. Car Industry: Charging Up the Future. Nature 2008, 456, 436. [CrossRef] [PubMed]

3. Tarascon, J.M.; Armand, M. Issues and Challenges Facing Rechargeable Lithium Batteries. Nature 2001, 414, 359-367. [CrossRef] [PubMed]

4. Yu, G.H.; Hu, L.B.; Vosgueritchian, M.; Wang, H.L.; Xie, X.; McDonough, J.R.; Cui, X.; Cui, Y.; Bao, Z.N. Solution-Processed Graphene/ $\mathrm{MnO}_{2}$ Nanostructured Textiles for High-Performance Electrochemical Capacitors. Nano Lett. 2011, 11, 2905-2911. [CrossRef] [PubMed]

5. Chmiola, J.; Largeot, C.; Taberna, P.L.; Simon, P.; Gogotsi, Y. Monolithic Carbide-Derived Carbon Films for Micro-Supercapacitors. Science 2010, 328, 480-483. [CrossRef] [PubMed]

6. Wang, G.P.; Zhang, L.; Zhang, J.J. A Review of Electrode Materials for Electrochemical Supercapacitors. Chem. Soc. Rev. 2012, 41, 797-828. [CrossRef] [PubMed]

7. Lu, Y.; Liu, X.M.; Wang, W.X.; Cheng, J.B.; Yan, H.L.; Tang, C.C.; Kim, J.K.; Luo, Y.S. Hierarchical, Porous CuS Microspheres Integrated with Carbon nanotubes for High-performance Supercapacitors. Sci. Rep. UK 2014, 1, 16584. [CrossRef] [PubMed]

8. Chen, J.; Minett, A.I.; Liu, Y.; Lynam, C.; Sherrell, P.; Wang, C.; Wallace, G.G. Direct Growth of Flexible Carbon Nanotube Electrodes. Adv. Mater. 2008, 20, 566-570. [CrossRef] 
9. Anh, V.; Qian, Y.Q.; Stein, A. Porous Electrode Materials for Lithium-Ion Batteries-How to Prepare Them and What Makes Them Special. Adv. Energy Mater. 2012, 2, 1056-1085. [CrossRef]

10. Cong, H.P.; Yu, S.H. Shape Control of Cobalt Carbonate Particles by a Hydrothermal Process in a Mixed Solvent: An Efficient Precursor to Nanoporous Cobalt Oxide Architectures and Their Sensing Property. Cryst. Growth Des. 2009, 9, 210-217. [CrossRef]

11. Zhou, H.; Han, G.; Chang, Y.; Fu, D.; Xiao, Y. Highly Stable Multi-wall Carbon Nanotubes@Poly (3,4-ethylenedioxythiophene)/Poly (styrene sulfonate) Core-shell Composites with Three-dimensional Porous Nano-network for Electrochemical Capacitors. J. Power Sources 2015, 274, 229-236. [CrossRef]

12. Zhang, S.L.; Pan, N. Supercapacitors Performance Evaluation. Adv. Energy Mater. 2014, 5, 1401401. [CrossRef]

13. Mahmooda, N.; Tahirb, M.; Mahmood, A.; Zhu, J.H.; Cao, C.B.; Hou, Y.L. Chlorine-doped Carbonated Cobalt Hydroxide for Supercapacitors with Enormously High Pseudocapacitive Performance and Energy Density. Nano Energy 2015, 11, 267-276. [CrossRef]

14. Salanne, M.; Rotenberg, B.; Naoi, K.; Kaneko, K.; Taberna, P.L.; Grey, C.P.; Dunn, B.; Simon, P. Efficient Storage Mechanisms for Building Better Supercapacitors. Nat. Energy 2016, 1, 16070. [CrossRef]

15. Zhong, Y.; Xia, X.H.; Shi, F.; Zhan, J.Y.; Tu, J.P.; Fan, H.J. Transition Metal Carbides and Nitrides in Energy Storage and Conversion. Adv. Sci. 2016, 3, 1500286. [CrossRef] [PubMed]

16. Wang, Y.C.; Zhou, T.; Jiang, K.; Da, P.M.; Peng, Z.; Tang, J.; Kong, B.; Cai, W.B.; Yang, Z.Q.; Zheng, G.F. Reduced Mesoporous $\mathrm{Co}_{3} \mathrm{O}_{4}$ Nanowires as Efficient Water Oxidation Electrocatalysts and Supercapacitor Electrodes. Adv. Energy Mater. 2014, 4, 1400696. [CrossRef]

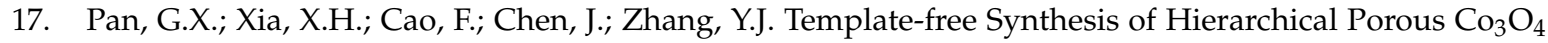
Microspheres and Their Application for Electrochemical Energy Storage. Electrochim. Acta 2015, 173, 385-392. [CrossRef]

18. Sun, X.L.; Hao, G.P.; Lu, X.Y.; Xi, L.X.; Liu, B.; Si, W.P.; Ma, C.S.; Liu, Q.M.; Zhang, Q.; Kaskel, S.; et al. High-defect Hydrophilic Carbon Cuboids Anchored with $\mathrm{Co} / \mathrm{CoO}$ Nanoparticles as Highly Efficient and Ultra-stable Lithium-ion Battery Anodes. J. Mater. Chem. A 2016, 4, 10166-10173. [CrossRef]

19. Zhang, G.H.; Wang, T.H.; Yu, X.Z.; Zhang, H.N.; Duan, H.H.; Lun, B.G. Nanoforest of Hierarchical $\mathrm{Co}_{3} \mathrm{O}_{4} @ \mathrm{NiCo}_{2} \mathrm{O}_{4}$ Nanowire Arrays for High-performance Supercapacitors. Nano Energy 2013, 2, 586-594. [CrossRef]

20. Yuan, C.Z.; Wu, H.B.; Xie, Y.; Lou, X.W. Self-sacrifice Template Formation of Hollow Hetero-Ni $\mathrm{S}_{6} / \mathrm{Co}_{3} \mathrm{~S}_{4}$ Nanoboxes with Intriguing Pseudocapacitance for High-performance Electrochemical Capacitors. Sci. Rep. UK 2014, 6, 20973. [CrossRef]

21. Luo, W.; Hu, X.L.; Sun, Y.M.; Huang, Y.H. Electrospun Porous $\mathrm{ZnCo}_{2} \mathrm{O}_{4}$ Nanotubes as a High-performance Anode Material for Lithium-ion Batteries. J. Mater. Chem. 2012, 22, 8916-8921. [CrossRef]

22. Wu, C.; Cai, J.J.; Zhang, Q.B.; Zhou, X.; Zhu, Y.; Li, L.J.; Shen, P.K.; Zhang, K.L. Direct Growth of Urchin-like $\mathrm{ZnCo}_{2} \mathrm{O}_{4}$ Microspheres Assembled from Nanowires on Nickel Foam as High-performance Electrodes for Supercapacitors. Electrochim. Acta 2015, 169, 202-209. [CrossRef]

23. Feng, Y.; Liu, J.H.; Wu, D.L.; Zhou, Z.Y.; Deng, Y.; Zhang, T.; Shi, K.M. Efficient Degradation of Sulfamethazine with $\mathrm{CuCo}_{2} \mathrm{O}_{4}$ Spinel Nanocatalysts for Peroxymonosulfate Activation. Chem. Eng. J. 2015, 280, 514-524. [CrossRef]

24. Gu, S.S.; Lou, Z.; Ma, X.D.; Shen, G.Z. $\mathrm{CuCo}_{2} \mathrm{O}_{4}$ Nanowires Grown on a Ni Wire for High-Performance, Flexible Fiber Supercapacitors. ChemElectroChem 2015, 2, 1042-1047. [CrossRef]

25. Wang, Q.F.; Xu, J.; Wang, X.F.; Liu, B.; Hou, X.J.; Yu, G.; Wang, P.; Chen, D.; Shen, G.Z. Core-Shell $\mathrm{CuCo}_{2} \mathrm{O}_{4} @ \mathrm{MnO}_{2}$ Nanowires on Carbon Fabrics as High-Performance Materials for Flexible, All-Solid-State, Electrochemical Capacitors. ChemElectroChem 2014, 1, 559-564. [CrossRef]

26. Yu, L.; Zhang, L.; Wu, H.B.; Lou, X.W. Formation of $\mathrm{Ni}_{\mathrm{x}} \mathrm{Co}_{3-\mathrm{x}} \mathrm{S}_{4}$ Hollow Nanoprisms with Enhanced Pseudocapacitive Properties. Angew. Chem. 2014, 126, 3785-3788. [CrossRef]

27. Yan, Z.Y.; Wang, B.R.; Xi, Y.X.; Xu, X.; Li, M.Y.; Li, J.; Coxon, P.; Cheng, S.D.; Gao, G.X.; Xiao, C.H.; et al. $\mathrm{A} \mathrm{NiCo}_{2} \mathrm{O}_{4}$ Nanosheet-mesoporous Carbon Composite Electrode for Enhanced Reversible Lithium Storage. Carbon 2016, 99, 633-641. [CrossRef]

28. Fu, C.C.; Li, G.S.; Luo, D.; Huang, X.S.; Zheng, J.; Li, L.P. One-Step Calcination-Free Synthesis of Multicomponent Spinel Assembled Microspheres for High-Performance Anodes of Li-Ion Batteries: A Case Study of $\mathrm{MnCo}_{2} \mathrm{O}_{4}$. ACS Appl. Mater. Interfaces 2014, 6, 2439-2449. [CrossRef] [PubMed] 
29. Mohamed, S.G.; Hung, T.F.; Chen, C.J.; Chen, C.K.; Hu, S.F.; Liu, R.S. Efficient Energy Storage Capabilities Promoted by Hierarchical $\mathrm{MnCo}_{2} \mathrm{O}_{4}$ Nanowire-based Architectures. RSC Adv. 2014, 4, 17230-17235. [CrossRef]

30. Gomez, J.; Kalu, E.E. High-performance Binder-free Co-Mn Composite Oxide Supercapacitor Electrode. J. Power Sources 2013, 230, 218-224. [CrossRef]

31. Yan, T.; Li, R.Y.; Zhou, L.; Ma, C.Y.; Li, Z.J. Three-dimensional Electrode of Ni/Co Layered Double Hydroxides@NiCo $\mathrm{S}_{4} @$ graphene@Ni Foam for Supercapacitors with Outstanding Electrochemical Performance. Electrochim. Acta 2015, 176, 1153-1164. [CrossRef]

32. Cai, D.P.; Liu, B.; Wang, D.D.; Wang, L.L.; Liu, Y.; Li, H.; Wang, Y.R.; Li, Q.H.; Wang, T.H. Construction of Unique $\mathrm{NiCo}_{2} \mathrm{O}_{4}$ Nanowire@CoMoO 4 Nanoplate Core/shell Arrays on Ni foam for High Areal Capacitance Supercapacitors. J. Mater. Chem. A 2014, 2, 4954-4960. [CrossRef]

33. Huang, G.Y.; Xu, S.M.; Xu, Z.H.; Sun, H.Y.; Li, L.Y. Core-Shell Ellipsoidal $\mathrm{MnCo}_{2} \mathrm{O}_{4}$ Anode with Micro-/Nano-structure and Concentration Gradient for Lithium-ion Batteries. ACS Appl. Mater. Interfaces 2014, 6, 21325-21344. [CrossRef] [PubMed]

34. Kuang, M.; Wen, Z.Q.; Guo, X.L.; Zhang, S.M.; Zhang, Y.X. Engineering Firecracker-like Beta-manganese Dioxides@Spinel Nickel Cobaltates Nanostructures for High-performance Supercapacitors. J. Power Sources 2014, 270, 426-433. [CrossRef]

35. Zeng, W.; Wang, L.; Shi, H.M.; Zhang, G.H.; Zhang, K.; Zhang, H.; Gong, L.F.; Wang, T.H.; Duan, H.G. Metal-organic-framework-derived $\mathrm{ZnO@C@NiCo} \mathrm{O}_{4}$ Core-shell Structures as an Advanced Electrode for High-performance Supercapacitors. J. Mater. Chem. A 2016, 4, 8233-8241. [CrossRef]

36. Wu, X.H.; Wu, W.W.; Wang, K.T.; Chen, W.; He, D. Synthesis and Electrochemical Performance of Flower-like $\mathrm{MnCo}_{2} \mathrm{O}_{4}$ as an Anode Material for Sodium Ion Batteries. Mater. Lett. 2015, 147, 85-87. [CrossRef]

37. Liu, M.T.; Fu, Y.; Ma, H.W.; Wang, T.L.; Guan, C.; Hu, K.R. Flower-like Manganese-cobalt Oxysulfide Supported on Ni Foam as a Novel Faradaic Electrode with Commendable Performance. Electrochim. Acta 2016, 191, 916-922. [CrossRef]

38. Huang, K.J.; Liu, Y.J.; Zhang, J.Z.; Liu, Y.M. A Sequence-specific DNA Electrochemical Sensor Based on Acetylene Black Incorporated Two-dimensional CuS Nanosheets and Gold Nanoparticles. Sens. Actuators B 2015, 209, 570-578. [CrossRef]

39. Pendashteh, A.; Moosavifard, S.E.; Rahmanifar, M.S.; Wang, Y.; El-Kady, M.F.; Kaner, R.B.; Mousavi, M.F. Highly Ordered Mesoporous $\mathrm{CuCo}_{2} \mathrm{O}_{4}$ Nanowires, a Promising Solution for High-performance Supercapacitors. Chem. Mater. 2015, 27, 3919-3926. [CrossRef]

40. Hu, W.; Chen, R.Q.; Xie, W.; Zou, L.L.; Qin, N.; Bao, D.H. CoNi ${ }_{2} \mathrm{~S}_{4}$ Nanosheet Arrays Supported on Nickel Foams with Ultrahigh Capacitance for Aqueous Asymmetric Supercapacitor Applications. ACS Appl. Mater. Interfaces 2014, 6, 19318-19326. [CrossRef] [PubMed]

41. Liu, L.F. Nano-aggregates of Cobalt Nickel Oxysulfide as a High-performance Electrode Material for Supercapacitors. Nanoscale 2013, 5, 11615-11619. [CrossRef] [PubMed]

42. Ghosh, D.; Das, C.K. Hydrothermal Growth of Hierarchical $\mathrm{Ni}_{3} \mathrm{~S}_{2}$ and $\mathrm{Co}_{3} \mathrm{~S}_{4}$ on a Reduced Graphene Oxide Hydrogel@Ni Foam: A High-energy-density Aqueous Asymmetric Supercapacitor. ACS Appl. Mater. Interfaces 2015, 7, 1122-1131. [CrossRef] [PubMed]

43. Cai, D.P.; Wang, D.D.; Wang, C.X.; Liu, B.; Wang, L.L.; Liu, Y.; Li, Q.H.; Wang, T.H. Construction of Desirable $\mathrm{NiCo}_{2} \mathrm{~S}_{4}$ Nanotube Arrays on Nickel Foam Substrate for Pseudocapacitors with Enhanced Performance. Electrochim. Acta 2015, 151, 35-41. [CrossRef]

44. Moosavifard, S.E.; Fani, S.; Rahmanian, M. Hierarchical $\mathrm{CuCo}_{2} \mathrm{~S}_{4}$ Hollow Nanoneedle Arrays as Novel Binder-free Electrodes for High-performance Asymmetric Supercapacitors. Chem. Commun. 2016, 52, 4517-4520. [CrossRef] [PubMed]

45. Wiltrout, A.M.; Read, C.G.; Spencer, E.M.; Schaak, R.E. Solution Synthesis of Thiospinel $\mathrm{CuCo}_{2} \mathrm{~S}_{4}$ Nanoparticles. Inorg. Chem. 2016, 55, 221-226. [CrossRef] [PubMed]

46. Wang, G.L.; Huang, J.C.; Chen, S.L.; Gao, Y.Y.; Cao, D.X. Preparation and Supercapacitance of CuO Nanosheet Arrays Grown on Nickel Foam. J. Power Sources 2011, 196, 5756-5760. [CrossRef]

47. Liu, Y.; Huang, H.W.; Peng, X.S. Highly Enhanced Capacitance of CuO Nanosheets by Formation of $\mathrm{CuO} / \mathrm{SWCNT}$ Networks through Electrostatic Interaction. Electrochim. Acta 2013, 104, 289-294. [CrossRef] 
48. Pang, M.J.; Long, G.H.; Jiang, S.; Ji, Y.; Han, W.; Wang, B.; Liu, X.L.; Xi, Y.L.; Wang, D.X.; Xu, F.Z. Ethanol-assisted Solvothermal Synthesis of Porous Nanostructured Cobalt Oxides $\left(\mathrm{CoO} / \mathrm{Co}_{3} \mathrm{O}_{4}\right)$ for High-performance Supercapacitors. Chem. Eng. J. 2015, 280, 377-384. [CrossRef]

49. Xu, P.P.; Ye, K.; Cao, D.X.; Huang, J.C.; Liu, T.; Cheng, K.; Yin, J.L.; Wang, G.L. Facile Synthesis of Cobalt Manganese Oxides Nanowires on Nickel Foam with Superior Electrochemical Performance. J. Power Sources 2014, 268, 204-211. [CrossRef]

(C) 2017 by the authors. Licensee MDPI, Basel, Switzerland. This article is an open access article distributed under the terms and conditions of the Creative Commons Attribution (CC BY) license (http://creativecommons.org/licenses/by/4.0/). 